20 Gispert JD, Pascau J, Reig S, Martinez-Lazaro R, Molina V, Garcia-Barreno P et al. Influence of the normalization template on the outcome of statistical parametric mapping of PET scans. Neuroimage 2003; 19: 601-12.

21 Hirvonen J, Goodwin RS, Li CT, Terry GE, Zoghbi SS, Morse C, et al. Reversible and regionally selective downregulation of brain cannabinoid CB1 receptors in chronic daily cannabis smokers. Mol Psychiatry 2012; 17: 642-9.

22 Tzourio-Mazoyer N, Landeau B, Papathanassiou D, Crivello F, Etard O, Delcroix N, et al. Automated anatomical labeling of activations in SPM using a macroscopic anatomical parcellation of the MNI MRI single-subject brain. Neuroimage 2002; 15: 273-89.

23 Fitzgerald PB, Oxley TJ, Laird AR, Kulkarni J, Egan GF, Daskalakis ZJ. An analysis of functional neuroimaging studies of dorsolateral prefrontal cortical activity in depression. Psychiatr Res 2006; 148: 33-45.

24 Soreide $\mathrm{K}$, Korner H, Soreide JA. Diagnostic accuracy and receiver-operating characteristics curve analysis in surgical research and decision making. Ann Surg 2011; 253: 27-34.

25 Brody AL, Saxena S, Stoessel P, Gillies LA, Fairbanks LA, Alborzian S, et al. Regional brain metabolic changes in patients with major depression treated with either paroxetine or interpersonal therapy: preliminary findings. Arch Gen Psychiatry 2001; 58: 631-40.

26 Holthoff VA, Beuthien-Baumann B, Zundorf G, Triemer A, Ludecke S, Winiecki $P$, et al. Changes in brain metabolism associated with remission in unipolar major depression. Acta Psychiatr Scand 2004; 110: 184-94.
27 Teneback CC, Nahas Z, Speer AM, Molloy M, Stallings LE, Spicer KM, et al. Changes in prefrontal cortex and paralimbic activity in depression following two weeks of daily left prefrontal TMS. J Neuropsychiatr Clin Neurosci 1999; 11: 426-35.

28 Zhang S, Ide JS, Li CS. Resting-state functional connectivity of the medial superior frontal cortex. Cereb Cortex 2012; 22: 99-111.

29 Exner C, Lange C, Irle E. Impaired implicit learning and reduced presupplementary motor cortex size in early-onset major depression with melancholic features. J Affect Disord 2009; 119: 156-62.

30 Almeida JR, Versace A, Hassel S, Kupfer DJ, Phillips ML. Elevated amygdala activity to sad facial expressions: a state marker of bipolar but not unipolar depression. Biol Psychiatry 2010; 67: 414-21.

31 Hosokawa T, Momose T, Kasai K. Brain glucose metabolism difference between bipolar and unipolar mood disorders in depressed and euthymic states. Progr Neuropsychopharmacol Biol Psychiatry 2009; 33: 243-50.

32 videbech P. PET measurements of brain glucose metabolism and blood flow in major depressive disorder: a critical review. Acta Psychiatr Scand 2000; 101: 11-20.

33 Suwa T, Namiki C, Takaya S, Oshita A, Ishizu K, Fukuyama $H$, et al. Corticolimbic balance shift of regional glucose metabolism in depressed patients treated with ECT. J Affect Disord 2012; 136: 1039-46.

AD EXTRA

\title{
reflection
}

\section{On Beyond Freedom and Dignity by B. F. Skinner}

\author{
Lynne M. Drummond
}

In 1971, the Western world was in the midst of the Cold War and debates raged about how we should act to ensure our long-term security and safety. In the same year, Burrhus Frederic Skinner published his highly controversial book, Beyond Freedom and Dignity. Already renowned as a behaviourist, author, social philosopher, inventor and professor of psychology at Harvard University, he set out to develop the ideas of how we could solve the world's growing problems. The controversial element was that, unlike conventional philosophical thought, Skinner did not consider man as fundamentally different from animals. Strongly influenced by Darwin's idea of natural selection, he believed that man, just like other animals, performs behaviours which are reinforcing or avoid aversive consequences. Unlike previous philosophers who believed that man has internal drives to do good, be heroic or make a choice to perform antisocial acts, Skinner believed these were outside our internal control and produced by environmental reinforcers. Applying strict scientific method, he wished to explore these complex reinforcers. He believed that social policy should encourage and reinforce desirable behaviours for the benefit of society at large. These views were not only against conventional religious and philosophical thought, but also against the continuous mantra that individuals should be free and able to make up their own minds about their actions without interference. Many critics appeared confused about what constitutes reinforcement and Skinner was often portrayed as advocating an overly punitive system of control. In fact, he advocated the use of positive reinforcers and some negative reinforcers. Positive reinforcers comprise tangible benefits (wealth, physical possessions) as well as social approval. Negative reinforcers are consequences which can be avoided by acting in a certain way. Skinner was not a believer in excessive use of punishment but felt people should be 'shaped' to behave better. No human being was truly free but made choices based on multiple, complex, and small environmental reinforcers, partially determined by our genetic structure. Dignity was an erroneous idea based on the concept of the 'inner man' being responsible for worthy acts as well as misdeeds: 'Almost all major problems involve human behavior, and they cannot be solved by physical and biological technology alone. What is needed is a technology of human behavior'.

The relevance of this work over 40 years later is striking. Today, we have the threats of environmental disasters, climate change, multiple wars and a population of over 7 billion. In the Western world we stand firm to the mantra that we must be free and must avoid allowing the politicians to develop a 'nanny state'. Despite this, when efforts have been made to alter the reinforcers for detrimental human behaviour, such as increasing social isolation of smokers, beneficial effects have been seen. All thinking individuals will resist any extreme introduction of state control and lack of freedom, but maybe the reinforcers are currently stacked to encourage antisocial rather than socially beneficial behaviours. Controversial trials of paying individuals to develop healthier lifestyles and lose weight have been implemented. Indeed, in cognitive-behavioural therapy we are now moving increasingly away from more cognitive models of treatment and back to examining the behavioural routes of many psychiatric syndromes. Perhaps it is time to revisit this thought-provoking and innovative book. 